Urol. int. 1965;19:163

\title{
Symposium III: Endocrinosurgical Treatment in Intersexuality
}

L'endocrinochirurgia negli stati intersessuali

L'endocrinochirurgie dans les états intersexuels

Endokrinochirurgie bei Intersexualität

Endocrinocirugia en los estados intersexuales

Chairman: Prof. R.G. Bunge

INDEX

Bunge, R.G. (Iowa City): What is Sex? Classification of Intersexes and

Methods of Diagnosis. The Existence of Intersexuality

165

Glenn, J.F. (Durham): Principles of Diagnosis and Treatment of Intersexuality

Money, J. (Baltimore): Psychology of Intersexes

Valle, G. (Bari): Problemi posti al ostetrico dai neonati intersessuali

Hinman, F. Jr. (San Francisco): Surgical Reversal of the Female Adrenal

Intersex

211

Overzier, C. (Mainz): Der echte Hermaphroditismus

222

B. Bunge

R. G. (Iowa City): Conclusions 